\title{
Food intake in lean and obese mice after peripheral administration of glucagon-like peptide 2
}

\author{
Sara Baldassano, Anna Lisa Bellanca, Rosa Serio and Flavia Mulè \\ Laboratorio di Fisiologia Generale, Dipartimento di Scienze e Tecnologie Molecolari e Biomolecolari (STEMBIO), Università di Palermo, Viale delle Scienze, \\ 90128 Palermo, Italy \\ (Correspondence should be addressed to F Mulè; Email: flavia.mule@unipa.it)
}

\begin{abstract}
We investigated the potential anorectic action of peripherally administered glucagon-like peptide 2 (GLP2) in lean and diet-induced obese (DIO) mice. Mice, fasted for $16 \mathrm{~h}$, were injected i.p. with native GLP2 or [Gly $\left.{ }^{2}\right] \mathrm{GLP} 2$, stable analog of GLP2, before or after GLP2 (3-33), a GLP2 receptor (GLP2R) antagonist, or exendin (9-39), a GLP1R antagonist. Food intake was measured at intervals 1, 2, 4, 8, and $24 \mathrm{~h}$ postinjection. In addition, we tested in lean mice the influence of $\left[\mathrm{Gly}^{2}\right] \mathrm{GLP} 2$ on gastric emptying and the effects of GLP1 alone or in combination with [Gly $\left.{ }^{2}\right]$ GLP2 on food intake. $\left[\mathrm{Gly}^{2}\right]$ GLP2 dose dependently and significantly inhibited food intake in lean and DIO mice. The reduction of food intake occurred in the first hour postinjection and it was sustained until $4 \mathrm{~h}$ postinjection in lean mice while it was
\end{abstract}

sustained until $2 \mathrm{~h}$ postinjection in DIO mice. GLP2 significantly inhibited food intake in both lean and DIO mice but only in the first hour postinjection. The efficiency of $\left[\mathrm{Gly}^{2}\right]$ GLP2 or GLP2 in suppressing food intake was significantly weaker in DIO mice compared with lean animals. The $\left[\mathrm{Gly}^{2}\right] \mathrm{GLP} 2$ anorectic actions were blocked by the GLP2R antagonist GLP2 (3-33) or by the GLP1R antagonist exendin (9-39). The coadministration of $\left[\right.$ Gly $\left.^{2}\right]$ GLP2 and GLP1 did not cause additive effects. $\left[\mathrm{Gly}^{2}\right]$ GLP2 decreased the gastric emptying rate. Results suggest that GLP2 can reduce food intake in mice in the short term, likely acting at a peripheral level. DIO mice are less sensitive to the anorectic effect of the peptide.

Journal of Endocrinology (2012) 213, 277-284

\section{Introduction}

Glucagon-like peptide 2 (GLP2) is a 33-amino acid peptide, produced by the processing of the proglucagon gene within the mucosal L-cells of the intestine and specific neurons located in the brainstem. The actions of GLP2 are transduced by the GLP2 receptor (GLP2R), which is localized within the gastrointestinal tract to enterendocrine cells, subepithelial myofibroblast cells, and in the neurons of the enteric nervous system (Estall \& Drucker 2006). In the CNS the GLP2R is expressed in the hypothalamic nucleus, the hippocampus, the nucleus of the solitary tract, the parabrachial nucleus, the supramammillary nucleus, and the substantia nigra (Vrang \& Larsen 2010). The main stimulus for the GLP2 release is represented by the presence of nutrients, specifically fats and carbohydrates, in the intestinal lumen (Brubaker 2006). After secretion, GLP2 is degraded by the enzyme dipeptidyl peptidase-IV (DPP-IV), which renders the peptide inactive by N-terminal truncation of the alanine at position 2 (Drucker et al. 1997). The degradation-resistant analog of GLP2, $\left[\mathrm{Gly}^{2}\right]$ GLP2 has increased efficacy compared with native GLP2 and is currently in clinical trials as a therapeutic for a variety of intestinal insufficiencies and diseases (Rowland \& Brubaker 2011).
The main site of action for the hormone peptide is the gastrointestinal tract where the peptide exerts trophic proprieties (Estall \& Drucker 2006). In addition to promoting expansion of the gastrointestinal mucosal surface area, GLP2 has been shown to affect gastrointestinal motility in humans and rodents. In fact, it inhibits gastric emptying (Wøjdemann et al. 1998, Nagell et al. 2004), decreases gastric fundic tone leading to enhancing gastric capacity (Amato et al. 2009), reduces intestinal transit in vivo (McDonagh et al. 2007), and reduces small and large intestinal motility in vitro (Amato et al. 2010, Cinci et al. 2011). The inhibitory effect on gastric tone, at least in mice, seems to depend on the nutritional state of the animal, being largely more evident in mice fed a high fat diet (HFD), which after 14 weeks develop obesity syndrome (Collins et al. 2004). In fact, diet-induced obese (DIO) animals have higher GLP2R expression in gastric fundus than mice fed a standard diet (lean animals) (Rotondo et al. 2011).

One still open question regarding the actions of GLP2 is about its importance in controlling food intake. Although GLP2 has been shown to decrease food intake in rodents when administered centrally (Tang-Christensen et al. 2000, Lovshin et al. 2001), it does not affect food consumption after peripheral administration in rodents or avian species, 
at least in long-term observations (Tsai et al. 1997, Shousha et al. 2007), probably because of the activity of GLP2 degrading enzyme DPP-IV. Thus, due to the lack of information about the effects of GLP2 on food consumption in the short term, the purpose of the present study was to clarify the potential role of GLP2 on feeding behavior within $24 \mathrm{~h}$. The efficiency of the long-acting GLP2 analog, $\left[\mathrm{Gly}^{2}\right] \mathrm{GLP} 2$, and of the native peptide was examined also in DIO mice to reveal any possible difference in comparison with lean animals.

\section{Materials and Methods}

\section{Animals}

Adult male C57BL/6J mice (Harlan Laboratories, San Pietro al Natisone, Udine, Italy) weighing about $18 \mathrm{~g}$ were housed individually in cages under standard conditions of light (12 h light: $12 \mathrm{~h}$ darkness cycle) and temperature $\left(22-24^{\circ} \mathrm{C}\right)$. We used adult male animals to avoid the effects of female reproductive hormones on food intake. Food and water were available ad libitum except otherwise indicated. All experimental procedures were approved by Ministero della Sanità (Rome, Italy) and were in compliance with the guidelines of the European Communities Council Directive of 24 November 1986.

\section{Diets}

After 1 week of free access to a pelletized rodent diet (GLP4RF21; Mucedola, S.r.L. Italy), mice were divided into two groups. One group were kept on the standard diet, which consisted of $18.5 \%$ proteins, $60 \%$ carbohydrates, and 3\% fats; the other group were fed a HFD (PF4051/D; Mucedola), which consisted of $23 \%$ proteins, 38\% carbohydrates, and 34\% fats $60 \%$ caloric fat content) for at least 14 weeks. At the end of this period, the body weight reached $38 \cdot 22 \pm 1 \cdot 1 \mathrm{~g}(n=30)$ in HFDfed mice and it was significantly different from the first group of animals (lean) $(27 \cdot 4 \pm 0 \cdot 9 \mathrm{~g} ; n=30)$.

\section{Peptides}

The following peptides were used: GLP2, GLP11 (7-36), exendin (9-39) (Tocris Bioscience, Bristol, UK), [Gly $\left.{ }^{2}\right]$ GLP2 and GLP2 (3-33) (Caslo Laboratory, Lyngby, Denmark).

\section{Experimental protocol}

Fasted $(16$ h) mice were injected i.p. with $100 \mu \mathrm{l}$ of either vehicle (PBS), [Gly ${ }^{2}$ GLP2 $(0 \cdot 15,0 \cdot 30,0 \cdot 60,0.90 \mu \mathrm{g} / \mathrm{g}$ b.w.), GLP1 (0.30 $\mu \mathrm{g} / \mathrm{g}$ b.w.), GLP2 (3-33) (0.90 $\mu \mathrm{g} / \mathrm{g}$ b.w.), exendin (9-39) $(0.20 \mu \mathrm{g} / \mathrm{g}$ b.w.), or GLP2 $(0.90 \mu \mathrm{g} / \mathrm{g}$ b.w.) in the early light phase (0800-0900 h). Prior to the initial study, mice received a daily i.p. injection of $100 \mu \mathrm{l}$ PBS for 7 days to habituate them to the procedure. To verify the mechanism of action some animals were injected i.p. with GLP2 (3-33) or exendin (9-39) immediately followed by PBS or $\left[\mathrm{Gly}^{2}\right]$ GLP2 or GLP1. The combined effects of [Gly $\left.{ }^{2}\right]$ GLP2 $(0.60 \mu \mathrm{g} / \mathrm{g}$ b.w.) and GLP1 $(0 \cdot 30 \mu \mathrm{g} / \mathrm{g}$ b.w.) were also analyzed. These concentrations for the joint study were chosen because they separately reduced food intake by $50 \%$ in the first hour.

Peptides were dissolved in PBS to concentrations that allowed delivery of dose in $100 \mu$ l. Doses were selected on the basis of previously published studies (Hartmann et al. 2000, Neary et al. 2005, Talsania et al. 2005, McDonagh et al. 2007) and pilot studies in our laboratory. A minimum of $72 \mathrm{~h}$ was allowed between each trial in the same mouse. Following injection, each mouse was returned to its home cage with a preweighed amount of chow. The food intake was determined at $1,2,4,8$, and $24 \mathrm{~h}$ following peptide or vehicle administration, by measuring the difference between the preweighed chow and the weight of chow at the end of each time interval. Any spillage was collected and weighed.

\section{Gastric emptying}

Lean mice were food deprived for $18 \mathrm{~h}$ with free access to water. At $t=0$ animals were given free access to preweighed standard chow for $1 \mathrm{~h}$, and then were injected i.p. with $100 \mu$ of either PBS or $\left[\mathrm{Gly}^{2}\right] \mathrm{GLP} 2(0.90 \mu \mathrm{g} / \mathrm{g}$ b.w.). Mice were deprived of food for $3 \mathrm{~h}$ after i.p. administration and then sacrificed. To determine the amount of food remaining in the stomach after the 3-h postinjection period, the stomach was excised and the gastric contents were collected, frozen, lyophilized overnight, and weighed. Total food intake during the 1-h feeding period was determined by measuring the difference between the preweighed standard chow and the weight of chow and spill. Gastric emptying (\%) was calculated as: $(1-$ (dry weight of food recovered from the stomach/total food intake) $\times 100$ ) (Talsania et al. 2005).

\section{Behavioral analysis}

Because it is possible that GLP2 inhibits food intake via nonspecific taste aversion, mice were observed for $1 \mathrm{~h}$ postinjection using a behavioral score sheet as described previously (Dakin et al. 2001). Four different behaviors (still, head down, burrowing, and locomotion) were scored in animals treated with PBS or GLP2 $(0.90 \mu \mathrm{g} / \mathrm{g}$ b.w. $)$ by observers blinded to the experimental conditions.

\section{Statistical analysis}

All data are expressed as means \pm s.E.M. Statistical significance was determined by ANOVA followed by Bonferroni's post-hoc test using Prism Version 4.0 software (GraphPad Software, Inc., San Diego, CA, USA). A $P$ value $<0 \cdot 05$ was considered to be statistically significant. 
Lean

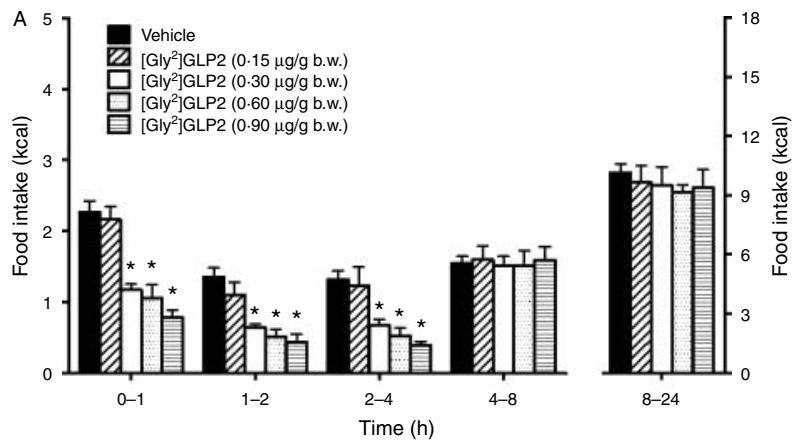

DIO

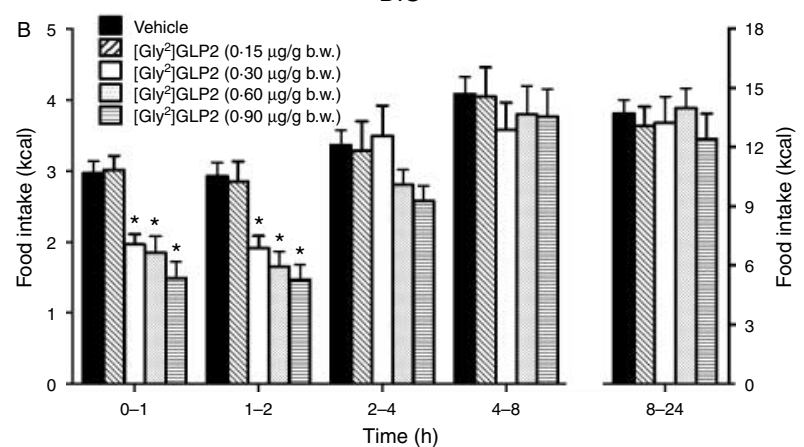

Figure 1 Effects of [Gly $\left.{ }^{2}\right]$ GLP2 on food intake in (A) lean and (B) DIO mice. Vehicle or $\left[\mathrm{Gly}^{2}\right] \mathrm{GLP} 2(0 \cdot 15,0 \cdot 30,0 \cdot 60$, and $0.90 \mu \mathrm{g} / \mathrm{g}$ b.w.) were injected i.p. in mice and food intake was measured at the intervals $0-1,1-2,2-4,4-8$, and $8-24 \mathrm{~h}$ postinjection. $n=8-10 /$ treatment. Data are means \pm s.E.M. ${ }^{*} P<0.05$ vs vehicle.

\section{Results}

Effects of $\left[G y^{2}\right] G L P 2$ administration on food intake in lean and DIO mice

I.p. administration of $\left[\mathrm{Gly}^{2}\right] \mathrm{GLP} 2(0 \cdot 15-0 \cdot 90 \mu \mathrm{g} / \mathrm{g}$ b.w. $)$ caused a dose-dependent and significant reduction in food intake when compared with vehicle-treated mice (Fig. 1A). The minimal dose of $\left[\mathrm{Gly}^{2}\right]$ GLP2 that had an effect was $0 \cdot 30 \mu \mathrm{g} / \mathrm{g}$ b.w. The decrease in food intake occurred from the first hour and was sustained until $4 \mathrm{~h}$ postinjection. The anorectic effect of $\left[\mathrm{Gly}^{2}\right] \mathrm{GLP} 2(0 \cdot 30-0 \cdot 90 \mu \mathrm{g} / \mathrm{g}$ b.w.) was abolished by previous administration of the GLP2R antagonist, GLP2 (3-33) (0.90 $\mu \mathrm{g} / \mathrm{g}$ b.w.) (Fig. 2A, B and C), which per se did not alter the food intake when compared with vehicle-treated mice (Fig. 3).

In DIO mice $\left[\mathrm{Gly}^{2}\right]$ GLP2 $(0 \cdot 15-0 \cdot 90 \mu \mathrm{g} / \mathrm{g}$ b.w.) induced a dose-dependent and significant reduction of food intake compared with PBS-treated mice. The lowest effective dose of [Gly $\left.{ }^{2}\right]$ GLP2 was $0 \cdot 30 \mu \mathrm{g} / \mathrm{g}$ b.w. The decrease in feeding was sustained with all doses for up to $2 \mathrm{~h}$ after injection. There were no significant differences in interval food intake at any other time point (Fig. 1B). The $\left[\mathrm{Gly}^{2}\right]$ GLP2 $(0 \cdot 30-0.90 \mu \mathrm{g} / \mathrm{g}$ b.w.) inhibition in feeding was abolished by previous injection of $0.90 \mu \mathrm{g} / \mathrm{g}$ b.w. of GLP2 (3-33), the GLP2R antagonist (Fig. 2D, E and F). Once more, GLP2 (3-33) per se did not alter the food intake when compared with vehicle-treated DIO mice.

The efficiency of i.p. $\left[\mathrm{Gly}^{2}\right] \mathrm{GLP} 2(0 \cdot 30-0 \cdot 90 \mu \mathrm{g} / \mathrm{g}$ b.w.) in suppressing food intake was significantly weaker in DIO mice than in lean animals (Fig. 4).

\section{Effect of GLP2 administration on food intake in lean and} DIO mice

To confirm the anorectic potential of the peptide we used the native GLP2 and measured food intake within $4 \mathrm{~h}$. In both lean and DIO mice administration of GLP2 $(0 \cdot 90 \mu \mathrm{g} / \mathrm{g}$ b.w.) significantly inhibited food intake in the first hour postinjection when compared with vehicle-treated mice and there were no significant changes in the food intake at any further interval. There was no change in still, head down, burrowing, and locomotion episodes in lean or DIO-treated mice compared with their respective controls. Once more,
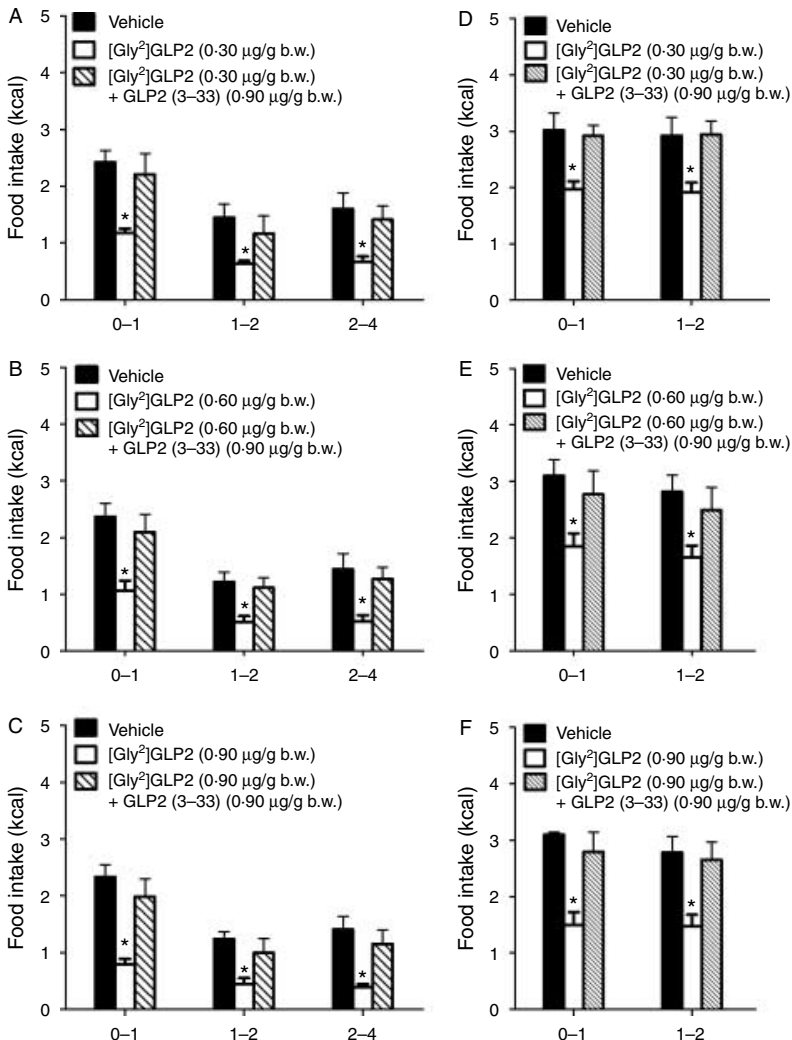

Figure 2 Effects of GLP2 (3-33), antagonist of GLP2R, on inhibitory effects induced by different doses of [Gly $\left.{ }^{2}\right]$ GLP2 on food intake in (A, B and C) lean and (D, E and F) DIO mice. Vehicle, [Gly ${ }^{2}$ ]GLP2, or GLP2 (3-33) (0.90 $\mu \mathrm{g} / \mathrm{g}$ b.w.), followed by [Gly $\left.{ }^{2}\right] \mathrm{GLP} 2$, were injected i.p. in mice and food intake was measured at the intervals $0-1,1-2$, and $2-4 \mathrm{~h}$ postinjection in lean animals ( $n=6-8 /$ treatment) or at the intervals $0-1$ and $1-2 \mathrm{~h}$ postinjection in DIO mice ( $n=6-8$ /treatment). Data are means + S.E.M. $* P<0.05$ vs vehicle. 


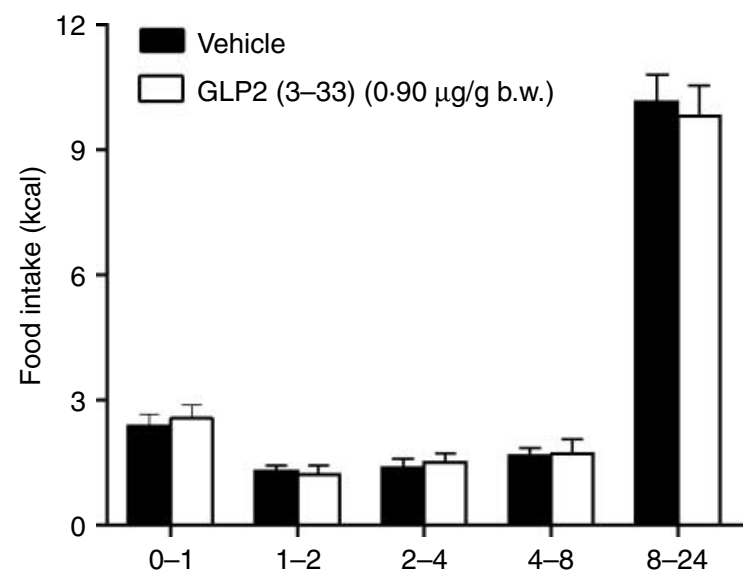

Figure 3 Effects of GLP2 (3-33) on food intake in lean mice. Mice were injected i.p. with vehicle or GLP2 (3-33) $(0.90 \mu \mathrm{g} / \mathrm{g}$ b.w.) and food intake was measured $0-1,1-2,2-4,4-8$, and $8-24 \mathrm{~h}$ postinjection. ( $n=6 /$ treatment). Data are means \pm S.E.M.

GLP2 was significantly less effective in DIO animals (Fig. 5A, $\mathrm{B}$ and $\mathrm{C})$.

\section{Cross talk between GLP1R and GLP2R}

In lean mice the anorectic effects of $\left[\mathrm{Gly}^{2}\right]$ GLP2 $(0.90 \mu \mathrm{g} / \mathrm{g}$ b.w.) were tested after injection of the GLP1R antagonist exendin (9-39) $(0 \cdot 20 \mu \mathrm{g} / \mathrm{g}$ b.w.). Administration of exendin (9-39) blocked the inhibitory effect of $\left[\mathrm{Gly}^{2}\right]$ GLP2, returning food intake to the same level as animals receiving injections of vehicle (Fig. 6). Exendin (9-39) $(0 \cdot 20 \mu \mathrm{g} / \mathrm{g}$ b.w.) alone did not alter food intake when compared with vehicle-treated mice.

Also GLP1 $(0 \cdot 30 \mu \mathrm{g} / \mathrm{g}$ b.w. $)$ decreased food intake. At the first hour, the reduction was of $-51 \cdot 5 \pm 6.0 \%$ $(n=12)$ relative to treatment with PBS and it was similar to that induced by a higher dose of [Gly $\left.{ }^{2}\right]$ GLP2 $(0.60 \mu \mathrm{g} / \mathrm{g}$ b.w. $)$ $(-53 \cdot 7 \pm 8 \cdot 0 \% ; n=8) \quad(P>0 \cdot 05$; Fig. 7). This effect was antagonized by exendin (9-39) $(0 \cdot 20 \mu \mathrm{g} / \mathrm{g}$ b.w.) but not by the GLP2R antagonist, GLP2 (3-33) $(0.90 \mu \mathrm{g} / \mathrm{g}$ b.w.) (data not shown). Furthermore, coadministration of $\left[\mathrm{Gly}^{2}\right]$ GLP2 $(0.60 \mu \mathrm{g} / \mathrm{g}$ b.w. $)$ and GLP1 $(0 \cdot 30 \mu \mathrm{g} / \mathrm{g}$ b.w.) caused a significant inhibition of feeding compared with PBS-treated animals, but additive inhibition was not observed because the percentage reduction in food intake $(-42 \cdot 8 \pm 6 \cdot 5 \% ; n=8)$ was not significantly different from the values observed after the peptides were individually administered (Fig. 7).

\section{Gastric emptying}

To examine potential mechanisms underlying the peptide anorectic action, the rate of gastric emptying was determined in mice administered PBS or [Gly ${ }^{2}$ GLP2 $(0.90 \mu \mathrm{g} / \mathrm{g}$ b.w.). Mice injected with $\left[\mathrm{Gly}^{2}\right] \mathrm{GLP} 2$ displayed a significant decrease in the rate of gastric emptying by $13 \cdot 1 \pm 0 \cdot 7 \%$ $(P<0 \cdot 01 ; n=8)$ compared with PBS-treated mice.

\section{Discussion}

The results of the present study suggest that GLP2 can enhance satiety in the short-term, although at pharmacological levels. Obese mice fed a HFD are less sensitive to the anorectic action of the peptide.

It is known that some products of the proglucagon, such as GLP1 or oxyntomodulin, are potent inhibitors of food intake when injected intracerebroventricularly in the animal model (Turton et al. 1996, Dakin et al. 2001) as well as when peripherally administered in both rodents and humans (Flint et al. 1998, Verdich et al. 2001, Cohen et al. 2003, Dakin et al. 2004, Liu et al. 2010). On the contrary, the potential importance and the mechanism of action responsible for the GLP2-dependent regulation of feeding behavior remain uncertain (Tang-Christensen et al. 2000, Lovshin et al. 2001, Schmidt et al. 2003, Sorensen et al. 2003). In fact, in healthy humans GLP2 does not affect appetite or postprandial feeling of satiety, although at concentrations that are not high enough to induce a response (Schmidt et al. 2003, Sorensen et al. 2003) or in patients with short bowel syndrome (Jeppensen et al. 2001). By contrast, GLP2 has been shown to be an inhibitor of food intake in rodents, when centrally injected (Tang-Christensen et al. 2000, Lovshin et al. 2001), but it is ineffective in long-term experiments when administered peripherally (Tsai et al. 1997, Scott et al. 1998). In addition, in the Japanese quail neither peripheral nor central administration of GLP2 affected food intake (Shousha et al. 2007), even if it is necessary to consider that the amino acid sequence of mammalian GLP2, used in the study shows low homology with the avian GLP2 (Burrin et al. 2003), explaining a possible inefficacy of mammalian GLP2 in the quail. In the present study, we examined the anorectic

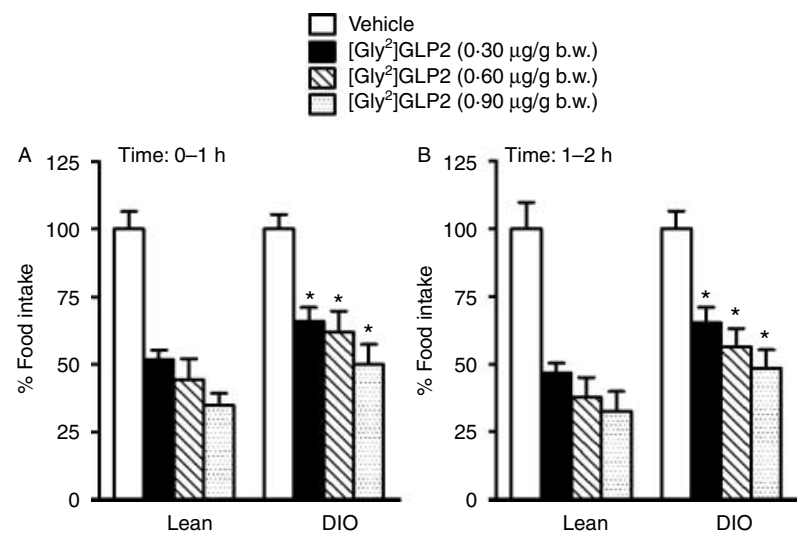

Figure 4 Comparison of the anorectic effect induced by [Gly $\left.{ }^{2}\right] \mathrm{GLP} 2$ in lean and DIO mice within the (A) first or the (B) second hour. Mice were injected with vehicle or $\left[\mathrm{Gly}^{2}\right] \mathrm{GLP} 2(0 \cdot 30,0 \cdot 60$, $0.90 \mu \mathrm{g} / \mathrm{g}$ b.w.) Data are means \pm S.E.M. ( $n=8-10 /$ treatment) and are expressed as a percentage of the mean food intake of the respective vehicle-treated animals. ${ }^{*} P<0 \cdot 05$ when compared with the respective $\left[G l y^{2}\right] G L P 2$ doses of the lean group. 

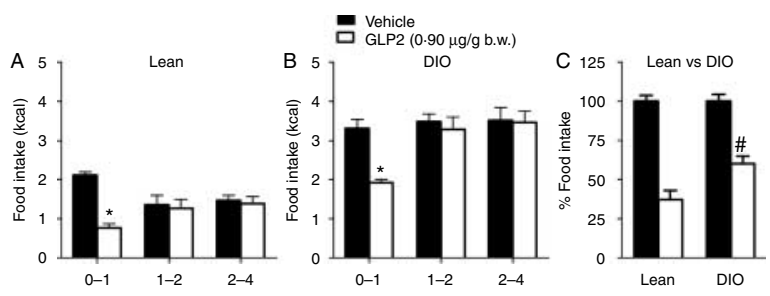

Figure 5 Effects of native GLP2 on food intake in (A) lean and (B) DIO mice. Vehicle or GLP2 $(0.90 \mu \mathrm{g} / \mathrm{g}$ b.w.) were injected i.p. in mice and food intake was measured at the intervals $0-1,1-2$, and 2-4 h postinjection. (C) Comparison of the anorectic action induced by GLP2 at the first hour postinjection. Results are expressed as a percentage of the mean food intake of the respective vehicle-treated animals. Data are means \pm S.E.M. $(n=8 /$ treatment $)$. ${ }^{*} P<0.05$ vs vehicle. ${ }^{\#} P<0 \cdot 05$ when compared with lean group.

potential of the peptide within $24 \mathrm{~h}$ and evaluated its efficacy also in DIO mice.

We found that $\left[\mathrm{Gly}^{2}\right]$ GLP2 caused a significant decrease in food intake; the effect was sustained until $4 \mathrm{~h}$ postinjection, while it failed to affect food intake in the long term, suggesting that the anorectic effect is transient. Interestingly, the dose of $\left[\mathrm{Gly}^{2}\right]$ GLP2 that inhibited the food intake by $50 \%$ was higher than that of GLP1, which resulted in $50 \%$ of inhibition $(0.60$ vs $0.30 \mu \mathrm{g} / \mathrm{g}$ b.w. respectively). Also the native GLP2 inhibited food intake, although its action was more transient than $\left[\mathrm{Gly}^{2}\right] \mathrm{GLP} 2$ and not detectable after $2 \mathrm{~h}$. Excessive degradation of GLP2 catalyzed by the ubiquitous enzyme DDP-IV (Hansen et al. 2007), which apparently renders the peptide inactive by $\mathrm{N}$-terminal truncation, could explain the difference in the effect duration. Moreover, we have ruled out that the reduction of food intake induced by GLP2 is due to nonspecific food aversion because behavioral analysis did not show any malaise signals.

Our results appear to be in contrast with previous reports in humans or rats (Scott et al. 1998, Jeppensen et al. 2001, Schmidt et al. 2003, Sorensen et al. 2003). However, Scott et al. (1998) did not measure food intake in the short term, but daily food intake. Moreover, in humans a variety of factors, such as psychological or environmental conditions, may influence meals. Another possible explanation may be that subjects were treated with GLP2 (Jeppensen et al. 2001, Schmidt et al. 2003, Sorensen et al. 2003), which is rapidly degraded.

To define the specificity of the anorectic GLP2 response, we tested the effect of $\left[\mathrm{Gly}^{2}\right]$ GLP2 after the injection with the GLP2R antagonist GLP2 (3-33) (Shin et al. 2005, Baldassano et al. 2009). GLP2 (3-33) completely blocked the anorectic effect of GLP2 in equivalent doses, without affecting the food intake reduction induced by GLP1, confirming the specificity of the response. The employed dose of GLP2 (3-33) had no effect on food intake per se, suggesting that GLP2R is not tonically activated.

Because in rodents a role for GLP1R signaling in the regulation of the central anorectic effects induced by i.c.v. injection of GLP2 has been proposed (Tang-Christensen et al.
2000, Lovshin et al. 2001), we used exendin (9-39) a GLP1R antagonist (Göke et al. 1993) to evaluate a possible cross talk between GLP1R and GLP2R signaling networks regulating food intake. In our experiments, similar to results obtained following i.c.v. infusion of GLP2 in rats (Tang-Christensen et al. 2000), the anorectic effects of $\left[\mathrm{Gly}^{2}\right]$ GLP2 were blocked by pretreatment with the GLP1R antagonist exendin (9-39), suggesting that the effects of GLP2 on feeding require the functional activity of GLP1R signaling. It is unlikely that $\left[\mathrm{Gly}^{2}\right]$ GLP2 directly interacts with GLP1R because previously it was reported that the peptide has no effect in cells transfected with GLP1R (Lovshin et al. 2001) and increases cAMP accumulation in neuronal cultures derived from GLP1R null mice (Lovshin et al. 2004). Indeed, the finding that exendin (9-39) eliminates the GLP2-mediated inhibitory effects on food intake might imply that the GLP1R antagonist acts also as a GLP2R antagonist, as in the past it was proposed (Wheeler et al. 1995, Munroe et al. 1999, Tang-Christensen et al. 2000). However, more recent studies clearly demonstrate that exendin (9-39) does not act as a functional GLP2R antagonist (Lovshin et al. 2001, 2004). In mice intracerebroventricular GLP2 inhibits dark-phase feeding more potently after GLP1R blockade or complete disruption of GLP1R in GLP1R knockout mice (Lovshin et al. 2001). The discrepancy with our results might be due to the route of administration (intracerebroventricular vs i.p.) and consequently a different site of action of the peptide. Results obtained in our experiments following coadministration suggest that GLP1 and GLP2 act through a common pathway because the effects of the peptides on the food intake were not additive.

On the basis of our results, we cannot conclude about the mechanism of action, i.e. whether the GLP2 inhibitory

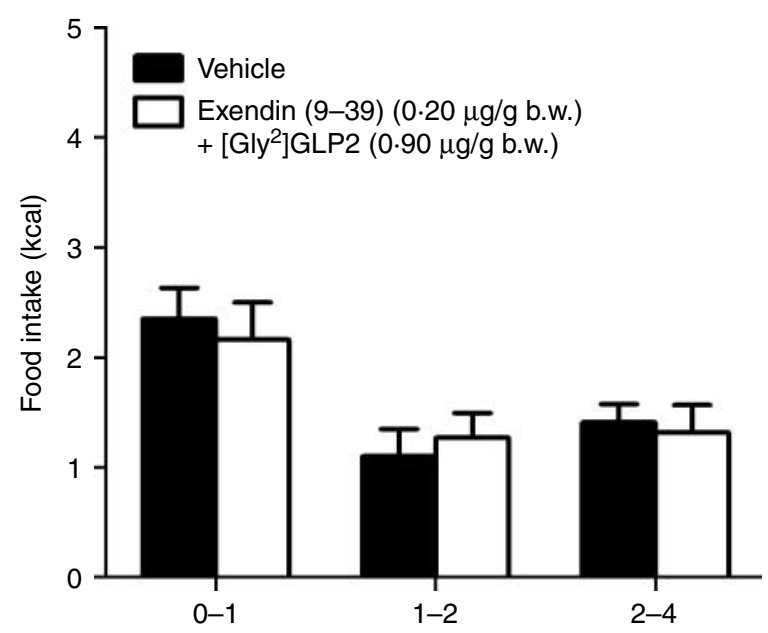

Figure 6 Effects of exendin (9-39), antagonist of GLP1R, on inhibitory effects induced by [Gly $\left.{ }^{2}\right] \mathrm{GLP} 2$ on food intake in lean mice. Vehicle or exendin (9-39) $(0 \cdot 20 \mu \mathrm{g} / \mathrm{g}$ b.w.) followed by $\left[\mathrm{Gly}^{2}\right]$ GLP2 $(0.90 \mu \mathrm{g} / \mathrm{g}$ b.w.) were injected i.p. in mice and food intake was measured at the intervals $0-1,1-2$, and $2-4 \mathrm{~h}$ postinjection. Data are means \pm S.E.M. $(n=6 /$ treatment $)$. 


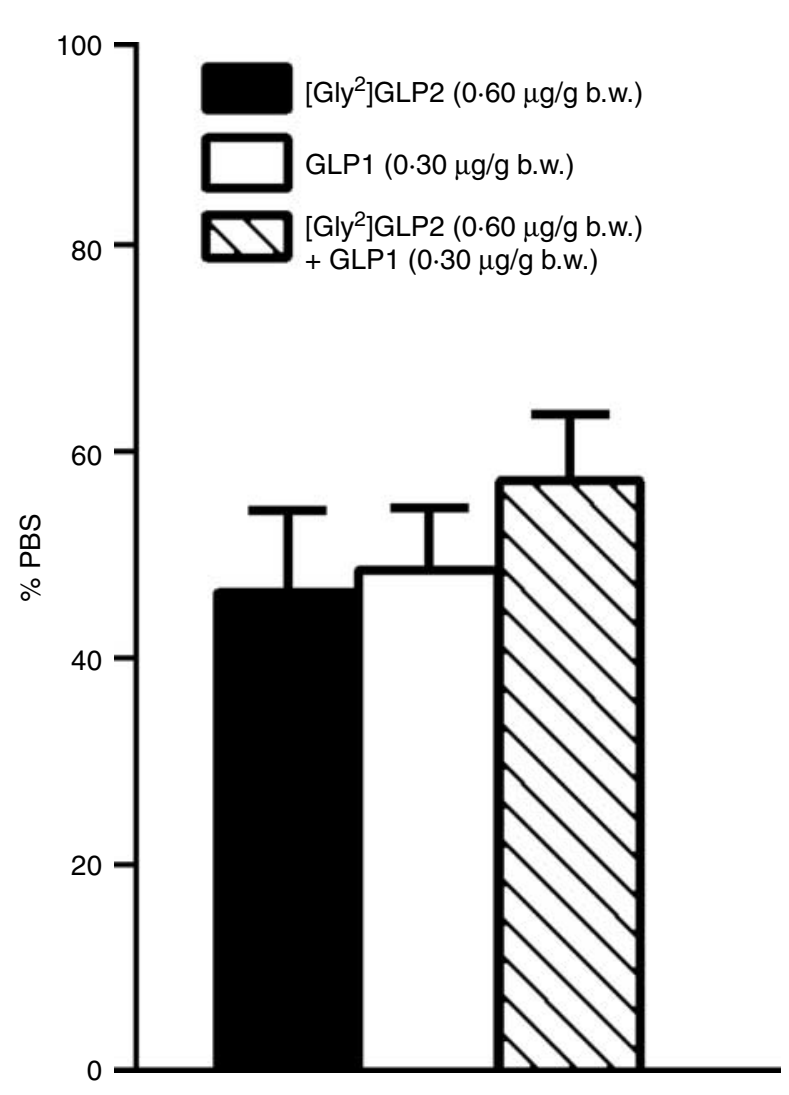

Figure 7 Effects of [Gly $\left.{ }^{2}\right] \mathrm{GLP} 2$ and GLP1, alone or in combination, on food intake in the first hour. Mice were injected i.p. with PBS, [Gly ${ }^{2}$ ]GLP2 (0.90 $\mu \mathrm{g} / \mathrm{g}$ b.w.), GLP1 $\left(0 \cdot 30 \mu \mathrm{g} / \mathrm{g}\right.$ b.w.), or [Gly ${ }^{2}$ ]GLP2 $(0.90 \mu \mathrm{g} / \mathrm{g}$ b.w. $)$ plus GLP1 $(0.30 \mu \mathrm{g} / \mathrm{g}$ b.w. $)$. Data are means \pm S.E.M. ( $n=8 /$ treatment) and are expressed as a percentage of the food intake in PBS-treated animals.

effect directly involves some of the brain centers regulating food intake or if it is indirect through peripheral sites. Indeed, participation of both central and peripheral sites in the GLP2induced anorectic effect might be considered because a number of studies have shown that peripheral administration of neuropeptides labels the blood-brain barrier-free area postrema and diffuses into the adjacent regions (Whitcomb et al. 1990), and GLP2Rs have been described in the nucleus of the solitary tract (Lovshin et al. 2004). In addition, functional GLP2R has been localized to the cell bodies of vagal afferents in the nodose ganglion, at least in the rat (Nelson et al. 2007), then i.p. GLP2 might activate vagal afferent pathways. However, decreased gastric motility may also be part of the premature inhibition of further ingestion as it constitutes a prandial satiety signal. Inhibition of gastric emptying (Wøjdemann et al. 1998, Nagell et al. 2004) and increased mouse gastric capacity induced by GLP2 have been described (Amato et al. 2009). Indeed, the observation that mice injected with $\left[\mathrm{Gly}^{2}\right] \mathrm{GLP} 2$ displayed a significant decrease in the rate of gastric emptying compared with PBS-treated mice strengthens the hypothesis that reduction in gastric emptying contributes to the short-term reduction in food intake.

In contrast, it is unlikely that the anorectic action of the peptide could be related to its well-known actions in the gastrointestinal tract, where it mediates adaptive increases in mucosal mass and increased transit time associated with increased segmental absorption of water, electrolytes, and nutrients, because the onset time of the anorectic effect is very short.

Another objective of the present study was to examine the effect of GLP2 on food intake in DIO mice, because the release of gut hormones is influenced by the content of the diet, in particular the fat content (Dakin et al. 2004), and a different sensitivity to intestinal hormones has been reported between lean and DIO models (Lin et al. 2000, Perreault et al. 2004). We found that DIO mice were less sensitive to the anorectic action of the peptide than lean animals. In fact, the magnitude and duration of the effects induced by similar doses of $\left[\mathrm{Gly}^{2}\right] \mathrm{GLP} 2$ were less pronounced in obese than lean animals and the native GLP2 was less effective in DIO mice. These observations appear particularly interesting because it has already been described that maintenance of rats on HFD reduces sensitivity to some satiety peptide signals (Covasa \& Ritter 1998, Covasa et al. 2001), principally the sensitivity to cholecystokinin (Covasa \& Ritter 1998, Covasa et al. 2001, Nefti et al. 2009).

In conclusion, our results show for the first time that the exogenous GLP2, administered peripherally, is able to reduce food intake in the short term, in both lean and DIO mice, although with a different efficacy, likely acting at the peripheral level.

\section{Declaration of interest}

The authors declare that there is no conflict of interest that could be perceived as prejudicing the impartiality of the research reported.

\section{Funding}

This work was supported by a grant from Ministero dell'Università e della Ricerca Scientifica, Italy.

\section{References}

Amato A, Baldassano S, Serio R \& Mulè F 2009 Glucagon-like peptide-2 relaxes mouse stomach through vasoactive intestinal peptide release. American Journal of Physiology. Gastrointestinal and Liver Physiology 296 G678-G684. (doi:10.1152/ajpgi.90587.2008)

Amato A, Rotondo A, Cinci L, Baldassano S, Vannucchi MG \& Mulè F 2010 Role of cholinergic neurons in the motor effects of glucagonlike peptide-2 in mouse colon. American Journal of Physiology. Gastrointestinal and Liver Physiology 299 G1038-G1044. (doi:10.1152/ ajpgi.00282.2010)

Baldassano S, Liu S, Qu MH, Mule' F \& Wood JD 2009 Glucagon-like peptide-2 modulates neurally-evoked mucosal chloride secretion in 
guinea pig small intestine in vitro. American Journal of Physiology. Gastrointestinal and Liver Physiology 297 G800-G805. (doi:10.1152/ajpgi. $00170.2009)$

Brubaker PL 2006 The glucagon-like peptides: pleiotropic regulators of nutrient homeostasis. Annals of the New York Academy of Sciences 1070 10-26. (doi:10.1196/annals.1317.006)

Burrin DG, Stoll B \& Guan X 2003 Glucagon-like peptide 2 function in domestic animals. Domestic Animal Endocrinology 24 103-122. (doi:10.1016/ S0739-7240(02)00210-2)

Cinci L, Faussone-Pellegrini MS, Rotondo A, Mulè F \& Vannucchi MG 2011 GLP-2 receptor expression in excitatory and inhibitory enteric neurons and its role in mouse duodenum contractility. Neurogastroenterology and Motility 23 383-392. (doi:10.1111/j.1365-2982.2011.01750.x)

Cohen MA, Ellis SM, Le Roux CW, Batterham RL, Park A, Patterson M, Frost GS, Ghatei MA \& Bloom SR 2003 Oxyntomodulin suppresses appetite and reduces food intake in humans. Journal of Clinical Endocrinology and Metabolism 88 4696-4701. (doi:10.1210/jc.2003030421)

Collins S, Martin TL, Surwit RS \& Robidoux J 2004 Genetic vulnerability to diet-induced obesity in the C57BL/6J mouse: physiological and molecular characteristics. Physiology \& Behavior 81 243-248. (doi:10.1016/j.physbeh. 2004.02.006)

Covasa M \& Ritter RC 1998 Rats maintained on high-fat diets exhibit reduced satiety in response to CCK and bombesin. Peptides 19 1407-1415. (doi:10.1016/S0196-9781(98)00096-5)

Covasa M, Marcuson JK \& Ritter RC 2001 Diminished satiation in rats exposed to elevated levels of endogenous or exogenous cholecystokinin. American Journal of Physiology. Regulatory, Integrative and Comparative Physiology 280 R331-R337.

Dakin CL, Gunn I, Small CJ, Edwards CM, Hay DL, Smith DM, Ghatei MA \& Bloom SR 2001 Oxyntomodulin inhibits food intake in the rat. Endocrinology 142 4244-4250. (doi:10.1210/en.142.10.4244)

Dakin CL, Small CJ, Batterham RL, Neary NM, Cohen MA, Patterson M, Ghatei MA \& Bloom SR 2004 Peripheral oxyntomodulin reduces food intake and body weight gain in rats. Endocrinology 145 2687-2695. (doi:10.1210/en.2003-1338)

Drucker DJ, Shi Q, Crivici A, Sumner-Smith M, Tavares W, Hill M, DeForest L, Cooper S \& Brubaker PL 1997 Regulation of the biological activity of glucagon-like peptide 2 in vivo by dipeptidyl peptidase IV. Nature Biotechnology 15 673-677. (doi:10.1038/ nbt0797-673)

Estall JL \& Drucker DJ 2006 Glucagon-like peptide-2. Annual Review of Nutrition 26 391-411. (doi:10.1146/annurev.nutr.26.061505.111223)

Flint A, Raben A, Astrup B \& Holst JJ 1998 Glucagon-like peptide 1 promotes satiety and suppresses energy intake in humans. Journal of Clinical Investigation 101 515-520. (doi:10.1172/JCI990)

Göke R, Fehmann HC, Linn T, Schmidt H, Krause M, Eng J \& Göke B 1993 Exendin-4 is a high potency agonist and truncated exendin(9-39)-amide an antagonist at the glucagon-like peptide 1-(7-36)-amide receptor of insulin-secreting beta-cells. Journal of Biological Chemistry 268 19650-19655.

Hansen L, Hare KJ, Hartmann B, Deacon CF, Ugleholdt RK, Plamboeck A \& Holst JJ 2007 Metabolism of glucagon-like peptide-2 in pigs: role of dipeptidyl peptidase IV. Regulatory Peptides 138 126-132. (doi:10.1016/j. regpep.2006.08.012)

Hartmann B, Thulesen J, Kissow H, Thulesen S, Orskov C, Ropke C, Poulsen SS \& Holst JJ 2000 Dipeptidyl peptidase IV inhibition enhances the intestinotrophic effect of glucagon-like peptide-2 in rats and mice. Endocrinology 141 4013-4020. (doi:10.1210/en.141.11.4013)

Jeppensen PB, Hartmann B, Thulesen J, Graff J, Lohmann J, Hansen BS, Tofteng F, Poulsen SS, Madsen JL, Holst JJ et al. 2001 Glucagon-like peptide 2 improves nutrient absorption and nutritional status in short-bowel patients with no colon. Gastroenterology 120 806-815. (doi:10.1053/gast. 2001.22555)

Lin S, Thomas TC, Storlien LH \& Huang XF 2000 Development of high fat diet induced obesity and leptin resistance in $\mathrm{C} 57 \mathrm{Bl} / 6 \mathrm{~J}$ mice. International Journal of Obesity 5 639-646. (doi:10.1038/sj.ijo.0801209)
Liu Y-L, Ford HE, Druce MR, Minnion JS, Field BCT, Schillito JC, Baxter J, Murphy KG, Ghatei MA \& Bloom SR 2010 Subcutaneous oxyntomodulin analogue administration reduces body weight in lean and obese rodents. International Journal of Obesity 34 1715-1725. (doi:10.1038/ ijo.2010.110)

Lovshin J, Estall J, Yusta B, Brown TJ \& Drucker DJ 2001 Glucagon-like peptide (GLP)-2 action in the murine central nervous system is enhanced by elimination of GLP-1 receptor signaling. Journal of Biological Chemistry 276 21489-21499. (doi:10.1074/jbc.M009382200)

Lovshin JA, Huang Q, Seaberg R, Brubaker PL \& Drucker DJ 2004 Extrahypothalamic expression of the glucagon-like peptide-2 receptor is coupled to reduction of glutamate-induced cell death in cultured hippocampal cells. Endocrinology 145 3495-3506. (doi:10.1210/en. 2004-0100)

McDonagh SC, Lee J, Izzo A \& Brubaker PL 2007 Role of glial cell-line derived neurotropic factor family receptor $\alpha 2$ in the actions of the glucagon-like peptides on the murine intestine. American Journal of Physiology. Gastrointestinal and Liver Physiology 293 G461-G468. (doi:10.1152/ajpgi.00424.2006)

Munroe DG, Gupta AK, Kooshesh F, Rizkalla G, Wang H, Demchyshyn L, Yang ZJ, Kamboj RK, Chen H, McCallum K et al. 1999 Prototypic G protein-coupled receptor for the intestinotrophic factor glucagon-like peptide 2. PNAS 96 1569-1573. (doi:10.1073/pnas.96.4.1569)

Nagell CF, Wettergren A, Pedersen JF, Mortensen D \& Holst JJ 2004 Glucagon-like peptide-2 inhibits antral emptying in man, but is not as potent as glucagon-like peptide-1. Scandinavian Journal of Gastroenterology 39 353-358. (doi:10.1080/00365520410004424)

Neary NM, Small CJ, Druce MR, Park AJ, Ellis SM, Semjonous NM, Dakin CL, Filipsson K, Wang F, Kent AS et al. 2005 Peptide YY3-36 and glucagon-like peptide-17-36 inhibit food intake additively. Endocrinology 146 5120-5127. (doi:10.1210/en.2005-0237)

Nefti W, Chaumontet C, Fromentin G, Tomé D \& Darcel N 2009 A high-fat diet attenuates the central response to within-meal satiation signals and modifies the receptor expression of vagal afferents in mice. American Journal of Physiology. Regulatory, Integrative and Comparative Physiology 296 R1681-R1686. (doi:10.1152/ajpregu.90733.2008)

Nelson DW, Sharp JW, Brownfield MS, Raybould HE \& Ney DM 2007 Localization and activation of glucagon-like peptide-2 receptors on vagal afferents in the rat. Endocrinology 148 1954-1962. (doi:10.1210/en.20061232)

Perreault M, Istrate N, Wang L, Nichols AJ, Tozzo E \& Stricker-Krongrad A 2004 Resistance to the orexigenic effect of ghrelin in dietary-induced obesity in mice: reversal upon weight loss. International Journal of Obesity $\mathbf{2 8}$ 879-885. (doi:10.1038/sj.ijo.0802640)

Rotondo A, Amato A, Baldassano S, Lentini L \& Mulè F 2011

Gastric relaxation induced by glucagon-like peptide- 2 in mice fed a high-fat diet or fasted. Peptides 32 1587-1592. (doi:10.1016/j.peptides. 2011.06.031)

Rowland KJ \& Brubaker PL 2011 The "cryptic" mechanism of action of glucagon-like peptide-2. American Journal of Physiology. Gastrointestinal and Liver Physiology 301 G1-G8. (doi:10.1152/ajpgi.00039.2011)

Schmidt PT, Näslund E, Grybäck P, Jacobsson H, Hartmann B, Holst JJ \& Hellström PM 2003 Peripheral administration of GLP-2 to humans has no effect on gastric emptying or satiety. Regulatory Peptides 116 21-25. (doi:10.1016/S0167-0115(03)00175-7)

Scott RB, Kirk D, MacNaughton WK \& Meddings JB 1998 GLP-2 augments the adaptive response to massive intestinal resection in rat. American Journal of Physiology 275 G911-G921.

Shin ED, Estall JL, Izzo A, Drucker DJ \& Brubaker PL 2005 Mucosal adaptation to enteral nutrients is dependent on the physiologic actions of glucagon-like peptide-2 in mice. Gastroenterology 128 1340-1353. (doi:10.1053/j.gastro.2005.02.033)

Shousha S, Nakahara K, Nasu T, Sakamoto T \& Murakami N 2007 Effect of glucagon-like peptide- 1 and -2 on regulation of food intake, body temperature and locomotor activity in the Japanese quail. Neuroscience Letters 415 102-107. (doi:10.1016/j.neulet.2007.01.007) 
Sorensen LB, Flint A, Raben A, Hartmann B, Holst JJ \& Astrup A 2003 No effect of physiological concentrations of glucagonlike peptide- 2 on appetite and energy intake in normal weight subjects. International Journal of Obesity and Related Metabolic Disorders 27 450-456. (doi:10.1038/sj.ijo.0802247)

Talsania T, Anini Y, Siu S, Drucker DJ \& Brubaker PL 2005 Peripheral exendin-4 and peptide YY(3-36) synergistically reduce food intake through different mechanisms in mice. Endocrinology 146 3748-3756. (doi:10.1210/en.2005-0473)

Tang-Christensen M, Larsen PJ, Thulesen J, Rømer J \& Vrang N 2000 The proglucagon-derived peptide, glucagon-like peptide-2, is a neurotransmitter involved in the regulation of food intake. Nature Medicine 6 802-807. (doi:10.1038/77535)

Tsai CH, Hill M, Asa SL, Brubaker PL \& Drucker DJ 1997 Intestinal growth promoting properties of glucagon-like peptide-2 in mice. American Journal of Physiology 273 E77-E84.

Turton MD, O'Shea D, Gunn I, Beak SA, Edwards CM \& Meeran K 1996 A role for glucagon-like peptide- 1 in the central regulation of feeding. Nature 379 69-72. (doi:10.1038/379069a0)

Verdich C, Flint A, Gutzwiller JP, Näslund E, Beglinger C, Hellström PM, Long SJ, Morgan LM, Holst JJ \& Astrup A 2001 A meta-analysis of the effect of glucagon-like peptide-1 (7-36) amide on ad libitum energy intake in humans. Journal of Clinical Endocrinology and Metabolism 86 4382-4389. (doi:10.1210/jc.86.9.4382)
Vrang N \& Larsen PJ 2010 Preproglucagon derived peptides GLP-1, GLP-2 and oxyntomodulin in the CNS: role of peripherally secreted and centrally produced peptides. Progress in Neurobiology 92 442-462. (doi:10.1016/j. pneurobio.2010.07.003)

Wheeler MB, Gelling RW, McIntosh CH, Georgiou J, Brown JC \& Pederson RA 1995 Functional expression of the rat pancreatic islet glucose-dependent insulinotropic polypeptide receptor: ligand binding and intracellular signaling properties. Endocrinology 136 4629-4639. (doi:10.1210/en.136.10.4629)

Whitcomb DC, Taylor IL \& Vigna SR 1990 Characterization of saturable binding sites for circulating pancreatic polypeptide in rat brain. American Journal of Physiology 259 G687-G691.

Wøjdemann M, Wettergren A, Hartmann B \& Holst JJ 1998 Glucagon-like peptide- 2 inhibits centrally induced antral motility in pigs. Scandinavian Journal of Gastroenterology 33 828-832. (doi:10.1080/00365529850171486)

Received in final form 27 March 2012

Accepted 28 March 2012

Made available online as an Accepted Preprint 28 March 2012 